\title{
EGY TOMPA TEST KÖRÜLI TURBULENS ÁRAMLAT NUMERIKUS IDŐ INTEGRÁCIÓS MÓDSZEREINEK A PARAMETRIKUS VIZSGÁLATA
}

\section{A NUMERICAL PARAMETRIC STUDY OF TIME INTEGRATION METHODS FOR TURBULENT FLOWS AROUND A BLUFF BODY}

\author{
Milchis Tudor ${ }^{1}$, Gobesz F.-Zsongor ${ }^{2}$ \\ Kolozsvári Müszaki Egyetem (UTCN), Épitömérnöki Kar, Tartószerkezetmechanikai \\ tanszék, Románia, 400020 Kolozsvár, C. Daicoviciu (Bástya) u. 15. \\ 'tudor.milchis@mecon.utcluj.ro \\ 2'go@mecon.utcluj.ro
}

\begin{abstract}
The numerical integration methods of the Navier-Stokes equations were parametrically studied in case of the airflow around a rectangular bluff-body. Three different artificially generated, 600 second long wind speed distributions were considered, with the variation of three significant parameters. The goal was not the assessment of the actual airflow around the body, but the study of the numerical integration methods implemented in Abaqus in terms of their convergence.
\end{abstract}

Keywords: fluid dynamics, turbulent flow system, numerical integration methods, parametric study

\section{Összefoglalás}

Egy nem aerodinamikus téglatest körüli légáramlat Navier-Stokes féle egyenleteinek a numerikus integrálási módszereit vizsgáltuk parametrikusan. Három eltérő, 600 másodperces időtartamú, mesterségesen generált szélsebesség eloszlást vettünk figyelembe és három (a folyadékáramlások dinamikájában fontos) paramétert változtattunk. A cél nem a folyadék testkörüli viselkedésének a tanulmányozása volt, hanem az Abaqus programcsomagba ültetett eljárások vizsgálata konvergencia szempontjából.

Kulcsszavak: áramlástan, turbulens áramlási rendszer, numerikus integrálási módszerek, parametrikus vizsgálat

\section{Bevezetés}

$\mathrm{Az}$ áramlástan alapvető egyenletei a Navier-Stokes (N-S) féle képletek segítségével vannak kifejezve összenyomható, illetve összenyomhatatlan folyadékok mozgásának az esetében. Ezeknek az egyenleteknek a közvetlen integrálása csupán a folyadékok lamináris áramlása esetén lehetséges. A turbulens áramlások esetében viszont egyszerüsített modelleket lehet bizonyos mértékig alkalmazni. A szakirodalomból elég sok parciális (N-S) differenciálegyenletek megoldására szolgáló eljárás közül lehet választani. Az Abaqus szoftvercsomagban három változat van beépítve (a 
„Backward-Euler”, a „Galerkin” és a „Trapezoid"). Ezek a leggyakrabban alkalmazott modellek a N-S egyenletek integrálásakor. Mindegyik eljárásnak megvannak a maga előnyei és hátrányai, van amelyiket hoszszabb időtartamú vizsgálatok esetében, van amelyiket apróbb $\Delta \mathrm{t}$ lépések számítása-kor elönyösebb alkalmazni [1-4].

\section{A Navier-Stokes féle egyenletek numerikus integrálási módjai}

A tömeg meg a lendület megmaradása és a termodinamika második törvénye a három alapvető elve az áramlástannak. A vizsgált tárgy körüli turbulens áramlás (tehát a nagyon magas Reynolds-szám) miatt az egyenletek matematikai megoldásához egy turbulens modell alkalmazását tette szükségessé. Az Abaqus szoftvercsomag alapértelmezésben a LES (Largy Eddy Simulations) modellt használja, de esetünkben, az áramlás nagyobb turbulenciája miatt egy bonyolultabb modellre, a „SpalartAllmaras"-ra esett a választásunk.

A szállítási egyenletek integrálása inkrementálisan történik, erre három változatot kínál az Abaqus a következő $\theta$ értékekkel: $1 / 2$ a ,Trapezoid”, $2 / 3$ a „Galerkin”, illetve 1 a „Backward-Euler” módszer esetében, és a következőket javasolja a három parametrizált eljárás esetében, a $\theta$ érték függvényében:

- a legtöbb esetben a „Trapezoid” illetve a „Galerkin" módszer alkalmazása javasolt, az idő-inkremens automatikus frissítésével;

- a „Backward-Euler” meg a „Galerkin” módszer sikeresen alkalmazható az állandó áramlású folyadékok esetében, amikor nincsenek hirtelen sebességváltozások.

\section{Számítási eredmények}

A számításokat egy $60 \times 30 \times 43$ m-es szerkezeten végeztük, egy $300 \times 500 \times 93 \mathrm{~m}$ es $(\mathrm{B} \times \mathrm{L} \times \mathrm{H})$ tartományban a szakirodalom- ban javasoltak [5-6] alapján. Az alkalmazott véges-elemek FC3D8 típusú 3D hexagonok (térbeli, 8 csomópontos térfogati elemek) voltak.

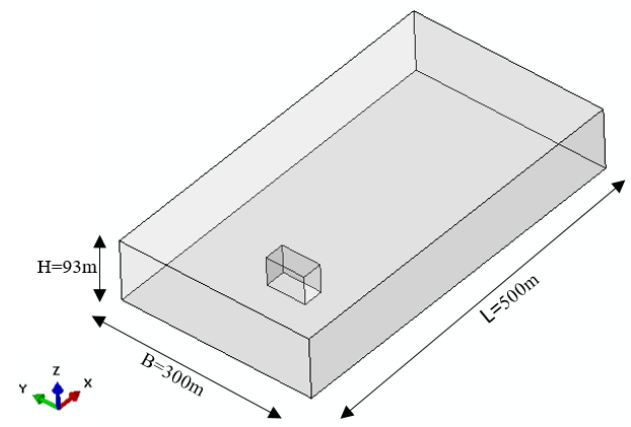

1. ábra. A vizsgált tartomány és test.
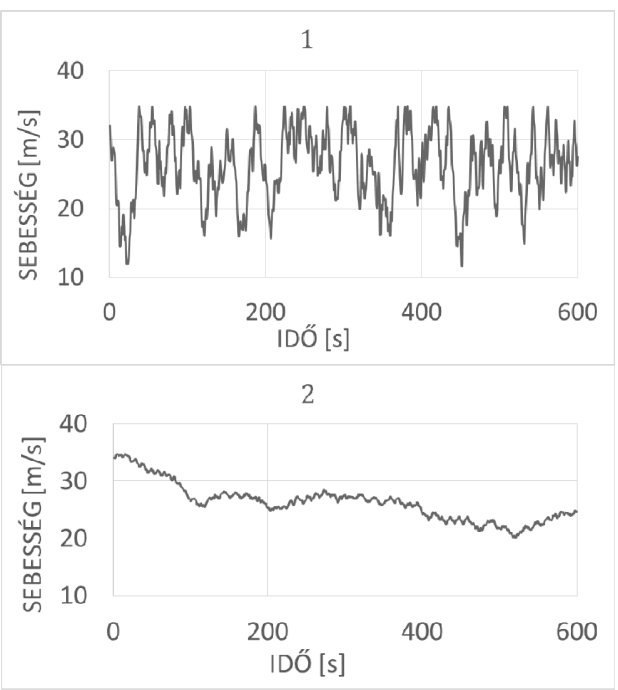

3

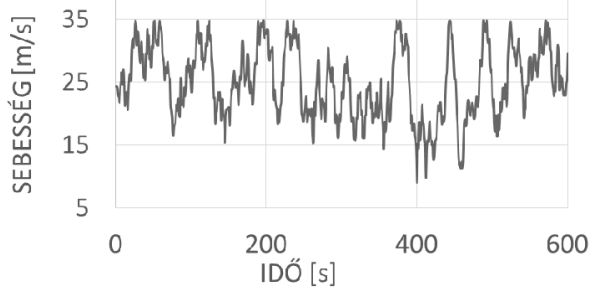

2. ábra. $A$ három mesterségesen generált, majd vizsgálatra alkalmazott sebességdiagramm. 
Egy tompa test körüli turbulens áramlat numerikus idö integrációs módszereinek a parametrikus vizsgálata

Az Abaqus szoftvercsomag megoldó programja hibrid megközelítést alkalmaz a tér- és időbeli tartomány véges-elemekre való felosztására. Az időfüggő feladatokhoz egy elörehaladott másodfokú vetítést alkalmaz 1 csomópontú véges-elemekkel (a csomópont az elem központjában van) a nyomás meghatározásához, teljesítve végestérfogatokhoz rendelt megmaradási jelenségeket. Ez a vetítési eljárás részben szétválasztja a nyomást a sebességtől a N-S egyenletekböl.

A „Spalart-Allmaras” módszer egyetlen szállítási differenciálegyenleten keresztül modellezi a turbulenciát.

Három különböző, mesterségesen generált sebességdiagrammot alkalmaztunk úgy, hogy a maximális szélsebesség ne lépje túl a $35 \mathrm{~m} / \mathrm{s}$-os határt (a 2. ábrán láthatók ezek a diagrammok). A paraméteres vizsgálat az alábbi három fontos érték változtatásaival történt:

- a véges-elemek mérete (1. táblázat $a$ és $b$ oszlop, méterben),

- a numerikus integrálási módszer (1. táblázat $e$ oszlop, jelölések: $B E-$ „Backward-Euler”, $T$ - „Trapezoid” és $G-$,Galerkin”),

- az igazítási lépés frekvenciája (1. táblázat $c$ oszlop).

Két zónában változtattuk a végeselemek méreteit: belül (a test és a folyadék érintkezési felületein $-b$ oszlop) és kívül (a terület többi részén $-a$ oszlop).

$\mathrm{Az}$ eredményeket három táblázatban összesítettük (1. táblázat), növekvő sorrendben a teljes 600 másodperces időtartam felé (ami a vizsgálat időrendi végét is jelenti, 1. táblázat $d$ oszlop). Egy-egy sikeres futtatás után nem végeztünk ismételt vizsgálatot, ami némileg zavarhatná e kutatás következtetéseit, de észrevehető egyes paraméterek stabilizálódása még a vizsgálat vége elött.
1. táblázat. A három sebességdiagrammból kapott adatok összesitése

\begin{tabular}{|c|c|c|c|c|}
\hline$a$ & $b$ & $c$ & $d$ & $e$ \\
\hline \multicolumn{5}{|c|}{1} \\
\hline 10 & 5 & 3 & 126,47 & $B E$ \\
\hline 10 & 5 & 1 & 131,99 & $B E$ \\
\hline 5 & 2,5 & 3 & 143,08 & $B E$ \\
\hline 5 & 2,5 & 3 & 155,51 & $B E$ \\
\hline 5 & 2,5 & 3 & 194,83 & $T$ \\
\hline 5 & 2,5 & 3 & 213,37 & $G$ \\
\hline 10 & 5 & 2 & 223,87 & $B E$ \\
\hline 7,5 & 7,5 & 3 & 233,36 & $T$ \\
\hline 7,5 & 4,5 & 3 & 256,66 & $T$ \\
\hline 7,5 & 5 & 3 & 270,87 & $B E$ \\
\hline 5 & 2,5 & 1 & 283,14 & $T$ \\
\hline 7,5 & 3 & 3 & 574,57 & $T$ \\
\hline 7,5 & 3 & 1 & 600,00 & $T$ \\
\hline \multicolumn{5}{|c|}{2} \\
\hline 5 & 1 & 2 & 25,33 & $T$ \\
\hline 7,5 & 2,5 & 3 & 60,60 & $T$ \\
\hline 7,5 & 5 & 1 & 71,00 & $G$ \\
\hline 7,5 & 2,5 & 8 & 77,46 & $T$ \\
\hline 7,5 & 5 & 3 & 83,00 & $B E$ \\
\hline 7,5 & 2,5 & 3 & 95,73 & $T$ \\
\hline 7,5 & 5 & 3 & 96,00 & $G$ \\
\hline 10 & 5 & 8 & 127,39 & $T$ \\
\hline 10 & 5 & 2 & 133,54 & $T$ \\
\hline 10 & 5 & 4 & 164,88 & $T$ \\
\hline 7,5 & 2,5 & 5 & 198,94 & $T$ \\
\hline 7,5 & 4,5 & 3 & 600,00 & $T$ \\
\hline \multicolumn{5}{|c|}{ 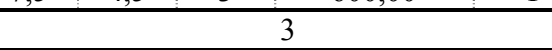 } \\
\hline 5 & 2 & 1 & 102,95 & $T$ \\
\hline 7,5 & 4,5 & 3 & 114,39 & $T$ \\
\hline 5 & 3 & 1 & 127,24 & $B E$ \\
\hline 7,5 & 5 & 1 & 131,22 & $B E$ \\
\hline 7,5 & 3,5 & 1 & 131,25 & $B E$ \\
\hline 7,5 & 3 & 1 & 267,93 & $B E$ \\
\hline 7,5 & 2 & 1 & 277,87 & $T$ \\
\hline 15 & 5 & 1 & 301,21 & $B E$ \\
\hline 7,5 & 3 & 1 & 325,39 & $G$ \\
\hline 7,5 & 3 & 1 & 356,79 & $T$ \\
\hline 10 & 5 & 1 & 369,93 & $B E$ \\
\hline 7,5 & 3 & 3 & 424,71 & $T$ \\
\hline 7,5 & 3 & 1 & 547,00 & $B E$ \\
\hline 7,5 & 3 & 3 & 600,00 & $G$ \\
\hline
\end{tabular}




\section{Következtetések}

A három szélsebesség változása között eltérések észlelhetők (az első és a harmadik némileg hasonló, de a második teljesen eltérő ezektől, kissebb sebességváltozásokkal). Bár első ránézésre úgy gondolhatnánk, hogy az első és a harmadik szélsebességi diagramm esetében azonos eljárást lehetne alkalmazni, az eredmények ezt cáfolják.

A második szélsebességi diagramm esetében nagyon nehézkes konvergenciát tapasztaltunk, ez a diagramm alakja miatt nem volt meglepö.

A harmadik diagramm esetében szükséges lett volna egy kiterjedtebb vizsgálat, de a futtatási / számítási idők terjedelme miatt lemondtunk erről. Általános megállapításként, a vizsgálatok futtatási ideje 24 óra körül volt egy 16 processzoros számítógép hálózaton $(2,8 \mathrm{GHz}$-es frekvenciával, 48 GB memóriával).

\section{Szakirodalmi hivatkozások}

[1] Yu D., Kareem A., Parametric study of flow around rectangular prisms using LES, Journal of Wind Engineering and Industrial Aerodynamics 77\&78,1998, 653-662.

[2] Immanuvel P., Arul Prakash K., Vengadesan S., Numerical analysis of laminar fluid flow characteristics past an elliptic cylinder: A parametric study, International Journal of Numerical Methods for Heat \& Fluid Flow, Vol. 24, 2014, 1570 - 1594.

[3] Fidaros D. K., Baxevanou C. A., Vlachos N. S., A parametric study of a solar calcinator using computational fluid dynamics, Energy Conversion and Management, Volume 48, Issue 11, November 2007, 19th International Conference on Efficiency, Cost, Optimization, Simulation and Environmental Impact of Energy Systems, 2007, 2784-2791.

[4] Sorvari J., Hämäläinen J., Time integration in linear viscoelasticity - a comparative study, Mech Time-Depend Mater, 2010, 307328.

[5] Anderson, J. D., Computational Fluids Dynamics. The Basics with Applications. McGraw-Hill Inc., 1995.

[6] Abaqus/CAE, Theory and user Manual.

[7] Barszcz T., Bielecka M., Bielecki A., Wojcik M., Wind speed modelling using Weierstrass function fitted by a genetic algorithm, Journal of Wind Engineering and Industrial Aerodynamics, No. 109, 2012, 68-78.

Acknowledgment:

The authors wish to express their gratitude for the funding and support received from the Department of Structural Mechanics, from the Technical University of Cluj-Napoca. 